\title{
Green Intelligent Home Energy Management System and Its Business Modeling
}

\author{
MingYue Zhai \\ School of Computer and Information Engineering \\ Guangdong University of Petrochemical Technology, Maoming, Guangdong Province, China
}

Keywords: GSHEMS; Business modeling; Standardization

\begin{abstract}
Energy internet emphasizes the entities to be interconnected and shared, where home energy management is an important constituent entities, the system need to consider the energy information of supply and demand in both the side of energy production and the side of load in order to realize the precise monitoring of energy and interaction among systems, and need to standardize the description of process. For this reason, this paper proposes a green intelligent home energy management system (GSHEMS) framework including both renewable energy and energy consumption, and introduces its composition and function, then gives the process of GSHEMS molding according to the general business model procedure for the energy Internet, which provides standardized guidance for the construction and deployment of business systems.
\end{abstract}

\section{Introduction}

Energy internet has become the trend of development with the main characteristics as interconnection, opening, sharing and equivalence in the energy industry of the future. As the constitute entity of the energy system, home will be inserted into the energy Internet in an equivalent form. Not only can the growth of distributed and renewable energy make home energy an autonomous system, also make it realize the bidirectional energy interaction with great power grid at the same time. Accordingly, the home energy management system need to consider both the production of renewable energy and the consumption of household electrical appliances and construct brand-new systematic structure in order to band more and more complicated function realization, ensure the balance between supply and demand and economize the cost of power.

Wider attention has been paid to the home energy management system(HEMS) by lots of scholars. Reference [1] presents home power optimization method based on the power line communication (PLC) through studying one household electronic appliance control module that can handle internet connection. Reference [2] presents the green home energy management system which can monitor, compare and control the consumption of home electrical appliance. Reference [3] studied hybrid power system which include solar power, wind power and tidal power. Reference [4] presents management system that strengthen the intelligent detection and control of household electrical appliance. Reference [5] presents the isolated island operation mode of home energy management when considering the system fault. But the distributed power production and the comprehensive analysis of load intelligent power consumption are not taken into consideration among these researches to realize the balance between supply and demand.

For this, a green intelligent home energy management system is presented, which is based on the energy internet interconnection, sharing characteristic and draws lessons from the idea of internet to make the integration of information, energy and infrastructure come true. This system includes not only the energy supply that is banded by distributed energy and great power grid, but also the intelligent control device with communication technology that intent to realize the load intelligent power consumption.

Meanwhile, normative description should be given to the service system for realizing the interaction among systems. This paper regards the green intelligent home energy management as a typical local area network(LAN) scene, models for it by the method presented in reference [6] and completes the system's normal description of three aspects as service general description, service 
function description and service content determination, at the same time, this passage provide theoretical foundation support for the disposal of service.

\section{Green Intelligent Home Energy Management System Framework}

There will be lots of distributed power sources in energy internet, among which the wind energy and photovoltaic power are most common form of distributed renewable energy in residential quarters. Intend to optimize the energy structure, home energy management system need to provide distributed renewable energy possessed by domestic consumers with support and back the implement of demand response in residential quarters. Through the HEMS, residential consumers appropriately make response to the dynamic dielectric signal published by the power corporation, optimize and control the power equipment to reduce the cost of power consumption and cut down the demand of power peak value. In addition, electric cars can also realize the charging in the network and eliminate the bad effects on power grid by use of the safe connection between home power-use network and power grid.

As is shown in the Fig. 1, GSHEMS mainly includes four kinds devices which are electricity load, distributed power sources, stockpile equipment and device of control and management. The core idea is that the kernel device intelligent manager in the system can realize that the energy management module and renewable energy sources gateway can monitor the consumption of the household electrical appliance and production of renewable power source respectively by the information and communication technology; is that gather and handle the data of power consumption and production, and optimize the energy dispatcher of power load according to the results of analysis through control technology and internet communication technology, and then realize demand response of residential quarter and optimize the consumption of energy and is that improve the power quality and utilization of wind energy and photovoltaic energy through stockpile equipment, realize the transaction of power sale with power grid and reduce the power cost of users according to the power demand analysis.

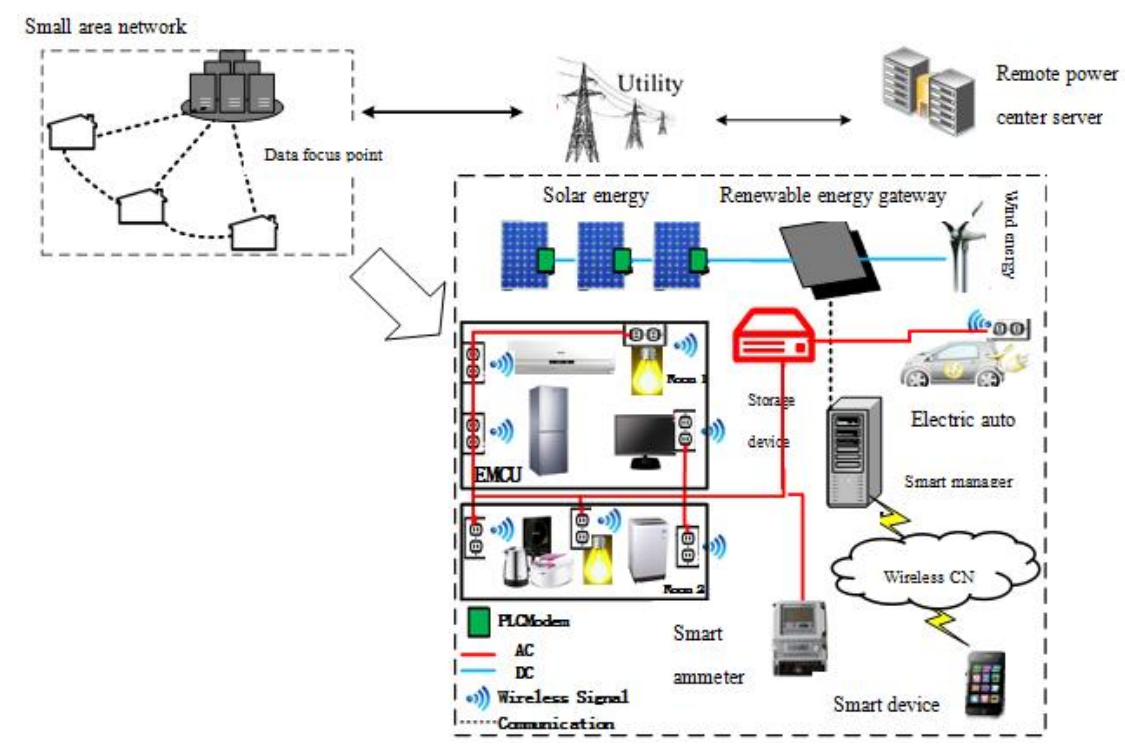

Figure 1. Green intelligent home energy management framework

On the side of load consumption, users can make use of intelligent devices to set up the demand of power manually and browse home energy information by visiting the intelligent manager through wireless internet. Intelligent manager can communicate with the energy measurement communication unit(EMCU) installed on every load. EMCU includes communication module and measurement module, which transform the measured value of consumption of load into the intelligent manager, then the manager collects and handles the data, and get the strategy(time, priority etc. ) of optimizing power consumption and reduce the cost of power by combining the 
results of analysis, demand of users and acquisition of power price.

On the side of power production of energy, the power production of solar energy and wind energy can be monitored by renewable energy gateway(REG). The PLC modulator-demodulator implanted in every solar energy panel will transmit the status of solar energy panel to the renewable energy gateway(REG) through communication technology. REG can use the communication technology to transmit the gathered status data to the intelligent manager, and then the intelligent manager analyze the data of power production of energy and combine the condition of power consumption of household electrical appliance to realize the supply of household load.

Just as the paragraph, home energy management system in the energy internet environment not only optimize and manage the energy consumption of single household, also work with other households, so the HEMS in the energy internet environment need support from three networks like home area network(HAN), small area network(NAN) and wide area network(WAN). Many intelligent managers transmit the information and data to the area control center, and then transmit to the power corporation through WAN in order to realize the functions like measurement, statistica, comparison and the subscribe to energy portal service, at the same time the control instructions of demand response, dispatcher strategy, power price and other information published by power corporation will be transmitted through the opposite path.

Moreover, for tackling the intermittence and randomness of wind energy and optical energy, intelligent manager can predict and estimate the condition of power production according to the power production data gathered in a period of time and the weather, and maintain the stability of system and improve utilization rate by using stockpile equipment. Power energy interaction among users and between users and great power grid in small area can be realized through the cooperation with the intelligent manager and data. For example, on the "valley bottom" of power demand, energy stockpile will absorb power energy from the power grid and provide the home with power for power-use load when power consumption peaks, or provide other uses with power in this area, or obtain the economic benefits through providing and selling power to the grid.

\section{Intelligent Home Energy Management Business Modeling}

Intend to ensure the reasonable and effective use of energy and reduce the users' cost of power consumption, HEMS in the Energy Internet environment need to achieve interaction and cooperation among families in an area. Based on the common method of specific energy internet business modeling and designing presented in document [6], this part will standardize the modeling procedure of GSHEMS business. And following is concrete introduction of the business overall description, business function definition and business content determination. 


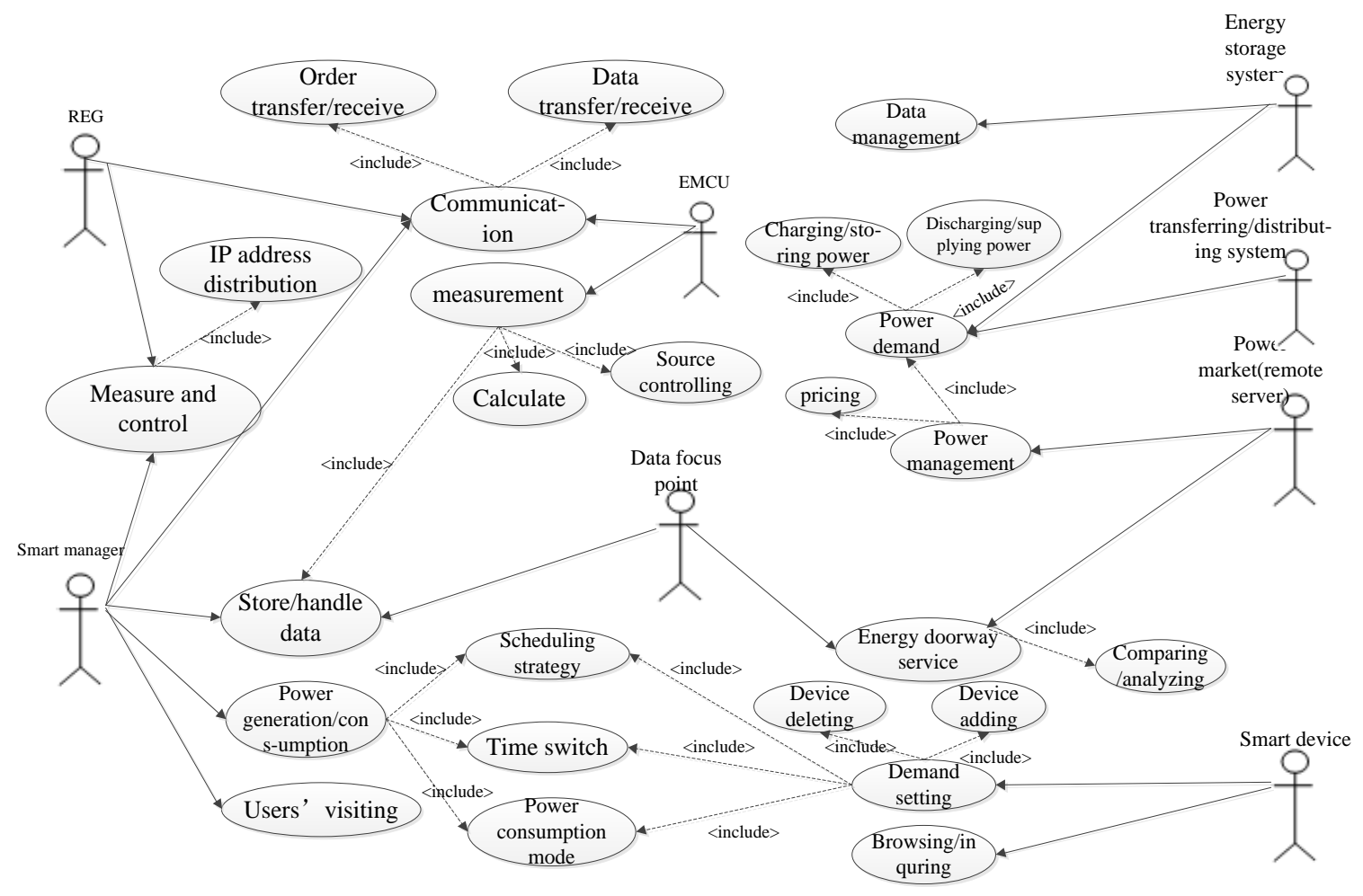

Figure. 2 Illustration of green intelligent home energy management in UML

Business overall description. Based on the framework presented in the previous section, GSHEMS is described in general through the UML case diagram. In the home network, the intelligent manager as an important unit, which needs to have data processing, power monitoring, communication, scheduling management and other functions to achieve reasonable scheduling and control among electricity load, energy storage equipment and renewable energy , and through the information Transmission and transmission and distribution system to participate in the electricity market price planning and power distribution, and finally achieve the home network energy storage equipment and transmission and distribution system energy transform in the electricity market regulation. It includes the following components.

Participators: intelligent terminal equipment, intelligent manager, EMCU, renewable energy gateway, energy storage equipment, data gathering point, power market (remote server), power transmission and distribution system.

Functions: Each participant has its own function of implementing energy management, as shown in Table 1: 
Table 1 Home energy management business composition table

\begin{tabular}{ll}
\hline $\begin{array}{l}\text { Business } \\
\text { Composition }\end{array}$ & Business Functions \\
\hline $\begin{array}{l}\text { intelligent } \\
\text { terminal } \\
\text { equipment }\end{array}$ & $\begin{array}{l}\text { Demand settings (device addition, deletion, power mode, timer } \\
\text { switch, etc.), query / browse. }\end{array}$ \\
$\begin{array}{l}\text { intelligent } \\
\text { manager }\end{array}$ & $\begin{array}{l}\text { Users access, monitor and control, power generation and energy } \\
\text { management, communication ( transmission / reception of data / } \\
\text { instruction), storage / processing of data. }\end{array}$ \\
EMCU & $\begin{array}{l}\text { Communication (transmission and reception of data and } \\
\text { instructions), measurement (power control, measurement). } \\
\text { Communication (transmission and reception of data and } \\
\text { instructions), monitoring and control (PLC modem assigns IP } \\
\text { address). } \\
\text { REG }\end{array}$ \\
$\begin{array}{l}\text { Data management, power requirements (charge / energy storage, } \\
\text { discharge / energy providing). } \\
\text { equipment } \\
\text { data gathering } \\
\text { point }\end{array}$ & $\begin{array}{l}\text { Storage / processing of data, portal services (comparison / } \\
\text { analysis, energy mode, scheduling strategy, etc.). } \\
\text { Power management (pricing, power demand), energy portal } \\
\text { services (comparison / analysis, method of energy use, etc.). }\end{array}$ \\
\hline
\end{tabular}

Combining energy storage equipment, transmission and distribution systems, electricity market to achieve energy demand management, pricing and service subscription.

Process: the entire illustration is divided into two parts. The one is that the user use intelligent terminal equipment to access the intelligent manager for manual settings, the family controller is combined with load power and renewable energy power generation data for scheduling and management. Another one is that energy storage equipment, data collection point, transmission and distribution System, the electricity market are supposed to participate in market pricing, and in accordance with market demand to achieve energy interaction.

The process of users using the terminal to access the intelligent manager to achieve power-use management:

When the appliance is added or removed, the intelligent terminal device is used to register the information on the intelligent manager and assign / revoke the IP address for the EMCU embedded in the appliance.

Intelligent Manager sends the information acquisition instruction to the EMCU and REG of every household electrical appliance, EMCU and gateway receive the instruction and analyze to complete the collection of household electrical appliances and renewable energy power generation information.

EMCU and REG feedback the collected data to the communication network and transmits it to the intelligent manager.

Intelligent Manager disposes and stores the collected data (filtering / computing / storage / analysis), and automatically set the optimal scheduling strategy to achieve home appliances scheduling and dynamic control (timing switch, Power mode, etc.) according to demand of users and collected information, .

Through the intelligent terminal equipment (mobile phones, computers, etc.) applications, users can access the intelligent manager, query / browse information through the wireless communication technology, and can also manually set the requirements .

information transmission process of Intelligent manager, data aggregation point and transmission and distribution system :

Multiple intelligent managers send collected home electricity information and energy generation information to the data aggregation point via the network. 
Data aggregation points upload data to the remote power server via a power distribution system.

Electricity companies conduct electricity management according to electricity information, set electricity price and set the demand for electricity, and transmit information and services according to the original path.

Under the participation of the power market, the relationship of the data gathering point, transmission and distribution system and energy storage system when achieve electricity power interaction:

Renewable energy power generation units supply electricity to the electricity load in the family of system.

When the power production is greater than the load power consumption, the energy storage equipment (energy storage / charging) will be charged by the remaining power to reduce the emergency power source of electric power system and power source system without power failure at the time when power consumption peaks and disaster. if there is surplus, combined with data analysis of data Aggregation point, the electric power will be sold to the family that has insufficient energy supply or sent to the power transmission and distribution system through the grid protection device.

When the generated electricity can not meet the load needs, energy storage equipment can be used to power supply (energy supply / discharge), if not enough, ,we can dispatcher the energy consumption among families or buy electric power from the company directly according to the data transmitted to the power company and the results of the analysis .

Business main function definition. 
Table 2. Family energy management business main function definition table

\begin{tabular}{|c|c|c|}
\hline $\begin{array}{l}\text { Business } \\
\text { Components }\end{array}$ & $\begin{array}{l}\text { Business } \\
\text { Function }\end{array}$ & Business Definition \\
\hline $\begin{array}{l}\text { Intelligent } \\
\text { terminal device }\end{array}$ & $\begin{array}{l}\text { Demand } \\
\text { setting }\end{array}$ & $\begin{array}{l}\text { Users log on the intelligent manager and set up } \\
\text { concrete demand of household electric device } \\
\text { manually via the communication network }\end{array}$ \\
\hline \multirow{3}{*}{ Intelligent } & $\begin{array}{l}\text { Monitor and } \\
\text { control/com } \\
\text { munication }\end{array}$ & $\begin{array}{l}\text { Transmitting the data/instruction according to the } \\
\text { IP address distributed to EMCU unit and realizing } \\
\text { the monitoring and control on the EMCU }\end{array}$ \\
\hline & $\begin{array}{l}\text { Store/handle } \\
\text { data }\end{array}$ & $\begin{array}{l}\text { Filtering, calculating and storing the gathered } \\
\text { power consumption data in the unit of } \\
\text { hour/day/month/ten-day/season/year and analyzing } \\
\text { the demand information correspondingly }\end{array}$ \\
\hline & $\begin{array}{l}\text { Power } \\
\text { generation } \\
\text { lenergy } \\
\text { consumption } \\
\text { management }\end{array}$ & $\begin{array}{l}\text { Setting up the household device table and } \\
\text { Realizing the strategic scheduling and control of } \\
\text { household electric appliance according to the data } \\
\text { analysis results; judging the power-supply(power } \\
\text { selling or buying) relation among renewable }\end{array}$ \\
\hline \multirow{3}{*}{ EMCU } & & $\begin{array}{l}\text { energy generation, power load and power } \\
\text { transmission and distribution system according to } \\
\text { the gathered data }\end{array}$ \\
\hline & $\begin{array}{l}\text { Measurement } \\
\text { and control }\end{array}$ & $\begin{array}{l}\text { Measuring the power, energy ,power factor, etc. } \\
\text { Controlling the power supply and break of families } \\
\text { on the basis of received instructions }\end{array}$ \\
\hline & $\begin{array}{l}\text { communicati } \\
\text { on }\end{array}$ & $\begin{array}{l}\text { Realizing the instruction reception/data } \\
\text { transmission with intelligent manager }\end{array}$ \\
\hline REG & $\begin{array}{l}\text { Monitoring } \\
\text { and } \\
\text { controlling/c } \\
\text { ommunicatio } \\
\mathrm{n}\end{array}$ & $\begin{array}{l}\text { Managing and controlling the modem labeled by } \\
\text { IP, transmitting the data/instruction, realizing the } \\
\text { collection and management of status data }\end{array}$ \\
\hline Storage system & $\begin{array}{l}\text { Power } \\
\text { demand }\end{array}$ & $\begin{array}{l}\text { Finishing the operation of energy storage/charging, } \\
\text { energy supply/discharging }\end{array}$ \\
\hline $\begin{array}{l}\text { Data } \\
\text { aggregation } \\
\text { point }\end{array}$ & $\begin{array}{l}\text { Store/handle } \\
\text { data }\end{array}$ & $\begin{array}{l}\text { Receiving and storing the power consumption } \\
\text { information of every intelligent manager and up } \\
\text { loading the information to the remote power center } \\
\text { server }\end{array}$ \\
\hline \multirow[b]{2}{*}{ Power market } & $\begin{array}{l}\text { Power } \\
\text { management }\end{array}$ & $\begin{array}{l}\text { Determining the power price and the power } \\
\text { demand strategy according to the gathered data } \\
\text { analysis results of power consumption }\end{array}$ \\
\hline & $\begin{array}{l}\text { Energy portal } \\
\text { service }\end{array}$ & $\begin{array}{l}\text { Power corporation receives power-use data from } \\
\text { different users and provides them with subscription } \\
\text { service }\end{array}$ \\
\hline
\end{tabular}

Business main content determination.In GSHEMS, the intelligent manager is the core unit of the system, it is the information exchange interface between home network and external network . With regard to the external side, it sends home energy-use information and energy demand to data 
aggregation point and power control center and receives power price information and dispatcher strategy. And in the home, it can realize the distribution, controlling and scheduling of all household appliances, renewable energy and energy storage system according to data analysis results. Fig. 3 is for the information transfer map of various components in the system:

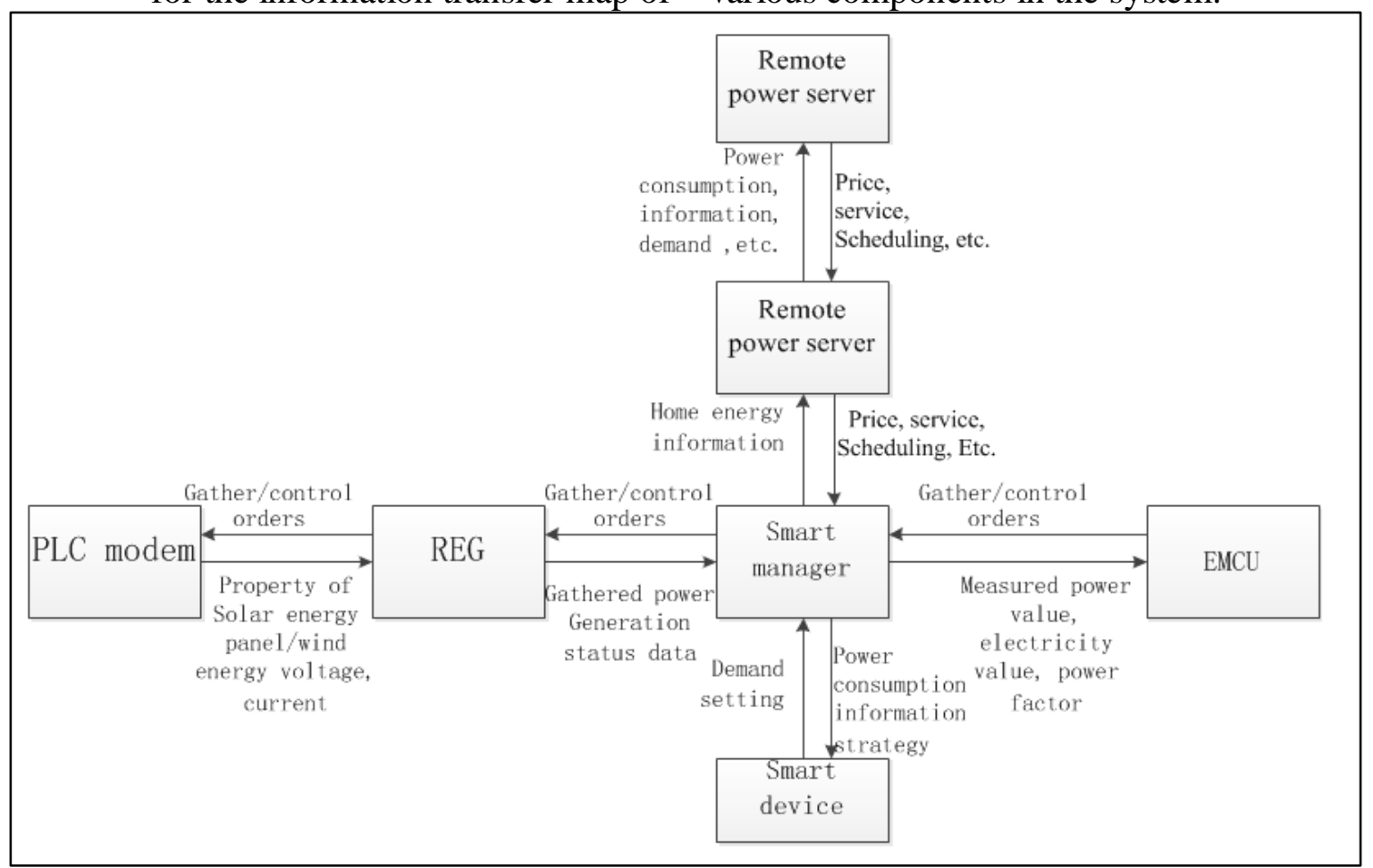

Figure 3. System information transmission diagram 
Table 3 Table of household energy management business

\begin{tabular}{|c|c|c|}
\hline $\begin{array}{l}\text { Business } \\
\text { Components }\end{array}$ & $\begin{array}{l}\text { Business } \\
\text { Function }\end{array}$ & Business Contents \\
\hline \multirow{3}{*}{$\begin{array}{l}\text { Intelligent terminal } \\
\text { device }\end{array}$} & Demand setting & $\begin{array}{l}\text { The power consumption mode, power demand,timing } \\
\text { switching time, functional characteristics and } \\
\text { classification(schedulability, non schedulability, etc.) }\end{array}$ \\
\hline & $\begin{array}{l}\text { Query } \\
\text { /browse }\end{array}$ & $\begin{array}{l}\text { and IP address of Household electrical appliance, } \\
\text { Standby power, power consumption and renewable } \\
\text { power generation of every household electric } \\
\text { appliance }\end{array}$ \\
\hline & $\begin{array}{l}\text { Monitoring and } \\
\text { controlling } \\
\text { /communicat-io } \\
\mathrm{n}\end{array}$ & $\begin{array}{l}\text { IP address, broadcast method, priority class, delay } \\
\text { and synchronous/asynchronous property of household } \\
\text { electric appliance }\end{array}$ \\
\hline \multirow[t]{2}{*}{ Intelligent manager } & handle & $\begin{array}{l}\text { IP address of household electric appliance, IP address } \\
\text { of PLC modem, electricity(voltage, current, active } \\
\text { power,reactive power, power factor, power grid } \\
\text { frequency,etc.) } \\
\text { in the }\end{array}$ \\
\hline & data & $\begin{array}{l}\text { hour/day/week/ten-day/month/year, renewable energy } \\
\text { generation(identified wind energy, property status } \\
\text { data of solar power generation system), instantaneity } \\
\text { or longevity, steadiness or dynamism of data }\end{array}$ \\
\hline \multirow{4}{*}{ EMCU } & $\begin{array}{l}\text { Power } \\
\text { generation/cons } \\
\text { umption } \\
\text { management }\end{array}$ & $\begin{array}{l}\text { Power purchasing information, power selling } \\
\text { information, storage information and operation device } \\
\text { table of household electric appliance }\end{array}$ \\
\hline & $\begin{array}{l}\text { Measurement } \\
\text { and control }\end{array}$ & $\begin{array}{l}\text { Control instruction, power value, electricity value and } \\
\text { power factor of household electric appliance }\end{array}$ \\
\hline & $\begin{array}{l}\text { Data } \\
\text { transmission }\end{array}$ & $\begin{array}{l}\text { Voltage value, current value, power value, electricity } \\
\text { value and power factor of household electric } \\
\text { appliance }\end{array}$ \\
\hline & $\begin{array}{l}\text { Instruction } \\
\text { reception }\end{array}$ & $\begin{array}{l}\text { Control instruction, local energy scheduling } \\
\text { instruction, power grid purchasing energy instruction }\end{array}$ \\
\hline REG & $\begin{array}{l}\text { Monitoring and } \\
\text { controlling/ } \\
\text { communicat-ion }\end{array}$ & $\begin{array}{l}\text { IP address of PLC modem, status data of solar energy } \\
\text { panel and wind energy generation }\end{array}$ \\
\hline Storage & Power demand & $\begin{array}{l}\text { Overall power consumption of every household } \\
\text { electric appliance, overall power generation and } \\
\text { pre-measurement of renewable energy }\end{array}$ \\
\hline $\begin{array}{l}\text { Data aggregation } \\
\text { point }\end{array}$ & Data storage & $\begin{array}{l}\text { GIS, overall power consumption, overall power } \\
\text { generation , overall power generation and } \\
\text { pre-measurement, local power selling information and } \\
\text { power purchasing information of every family }\end{array}$ \\
\hline \multirow{3}{*}{ Power market } & $\begin{array}{l}\text { Power energy } \\
\text { management }\end{array}$ & GIS and power consumption data of every family \\
\hline & $\begin{array}{l}\text { Energy portal } \\
\text { service }\end{array}$ & $\begin{array}{l}\text { GIS, power consumption data gains by power selling } \\
\text { and cost of power purchasing of every family }\end{array}$ \\
\hline & Pricing & $\begin{array}{l}\text { Real-time power price of different time and selling to } \\
\text { the power grid, }\end{array}$ \\
\hline
\end{tabular}




\section{Summary}

In the energy Internet environment, the electricity network in the household environment constitutes a home micro-grid with electricity load, energy storage systems, distributed power and other equipment. In this paper, GSHEMS, which integrates renewable energy power generation and energy use, is proposed to support the implementation of demand response, distributed power supply and electric vehicle access network, and the control technology and network communication technology are used to optimize energy consumption strategy and improve the efficiency of electricity consumption. A brief description of the business based on the general modeling method contribute to the interaction among the systems and work together for providing the design and deployment of GSHEMS with a solution, that will promote the full realization of the energy Internet. The standard description of the business is still in the preliminary research stage, the detailed modeling process has yet to be further studied.

\section{References}

[1] Young-Sung Son and Kyeong-Deok Moon. Home energy management system based on power line communication[C]. IEEE International Conference on Consumer Electronics, Las Vegas, USA, 2010, 115-116.

[2] Jinsoo Han, Chang-Sic Choi, Wan-Ki Park, and Ilwoo Lee. Green home energy management system through comparison of energy usage between the same kinds of home appliances[C]. IEEE International Symposium on Consumer Electronics, Singapore, 2011, 1-4.

[3] Chia-Hung Lien, Hsien-Chung Chen, Ying-Wen Bai, and Ming-Bo Lin. Power monitoring and control for electric home appliances based on power line communication[C]. IEEE International Instrumentation and Measurement Technology Conference, British Columbia, Canada, 2008, 2179-2184.

[4] Saeed Jahdi and Loi Lei Lai. Grid integration of wind-solar hybrid renewable using AC/DC converters as DG power sources[J]. World Congress Sustainable Technologies, London, UK, 2011,171-177.

[5] Hayato Yamauchi, Kosuke Uchida, and Tomonobu Senjyu. Advanced Smart Home[C]. IEEE International Conference on Harmonics and Quality of Power, Hong Kong, China, $2012,130-135$.

[6] LIN Weimin, HU Ziwei, GUO Jinghong, ZHOU Jing, LIAO Zhijun. Research on business modeling mechanism for Energy Internet[C].Global Energy Internet Conference, 2016, 1000-1006.

[7] Jinsoo Han, Chang-Sic Choi, Wan-Ki Park, Ilwoo Lee, and Sang-HaKim. Smart home energy management system including renewable energy based on ZigBee and PLC[C]. IEEE International Conference on Consumer Electronics, Las Vegas, USA, 2014,198-202.

[8] J.Y. Wang, J.H. Guo, J.H. Cao, L.CH. Gao, Z.W. Hu, J. Zhou, etc. The Key Technology Overall Description of Energy Internet Information Communication In Chinese[J]. Intelligent Power Grid In Chinese, 2015, 3(6), 1-10.

[9] P. Ai and Z. Shi. Overall Description of Business Modeling Technology In Chinese[J]. Computer Appliance and Software In Chinese, 2012, 29(7), 1-6. 